\title{
AGE, GROWTH, AND REPRODUCTION OF DENTEX MAROCCANUS (ACTINOPTERYGII: PERCIFORMES: SPARIDAE) IN THE SAROS BAY (NORTH AEGEAN SEA)
}

\author{
Guzin GUL, Ali ISMEN, and Mukadder ARSLAN* \\ Çanakkale Onsekiz Mart University, Faculty of Marine Science and Technology, Çanakkale, Turkey
}

Gul G., Ismen A., Arslan M. 2014. Age, growth, and reproduction of Dentex maroccanus (Actinopterygii: Perciformes: Sparidae) in the Saros Bay (north Aegean Sea). Acta Ichthyol. Piscat. 44 (4): 295-300.

\begin{abstract}
Background. The Morocco dentex, Dentex maroccanus Valenciennes, 1830, is a sparid species, which has economical value and its population is expanding in a $20-500 \mathrm{~m}$ depth range throughout the Mediterranean. Worldwide, there is a lack of information about the biology (age, growth, reproductive season, first maturity length) of this species. This study provides the first data on population parameters of D. maroccanus in the Aegean Sea.

Materials and methods. Dentex maroccanus were caught in the Saros Bay (north Aegean Sea) between September 2006 and September 2008. The length-weight relations were determined according to the allometric equation: $W=a L^{b}$. The spawning season was determined by analyzing the maturity stages and gonadosomatic index, while first maturity length was defined as the size at which $50 \%$ of individuals were mature. Growth parameters were estimated using the von Bertalanffy growth equation.

Results. The female-male ratio was $4.8: 1$. The total length (weight) of females ranged from $11.4 \mathrm{~cm}$ to $25.2 \mathrm{~cm}$ $(26.2 \mathrm{~g}$ to $289.3 \mathrm{~g}$ ) and of males from $12.8 \mathrm{~cm}$ to $24.3 \mathrm{~cm}$ (19.8 g to $223.9 \mathrm{~g})$. The growth parameters were calculated as $L_{\infty}=25.31 \mathrm{~cm}, K=0.49$ year $^{-1}, t_{0}=-0.30$ year. The length at first maturity for females and males was $13.0 \mathrm{~cm}$ and $15.8 \mathrm{~cm}$, respectively. Monthly values of the gonadosomatic index indicated that spawning occurred mainly between June and September.

Conclusion. Results reported in this work will contribute to the knowledge on the biology of D. maroccanus in the north Aegean Sea and also to a better understanding of its role in the marine ecosystem.
\end{abstract}

Keywords: Morocco dentex, otolith, growth, maturity, North Aegean Sea

\section{INTRODUCTION}

In the Mediterranean, sea breams (Sparidae) are represented by 22 species belonging to 10 genera (Arculeo et al. 2003), of which 14 species are also found in the north Aegean Sea (İşmen et al. unpublished**). The Morocco dentex, Dentex maroccanus Valenciennes, 1830, is an important demersal commercial sparid species inhabiting depths ranging from 20 to $500 \mathrm{~m}$ and can be found throughout the Mediterranean (absent in the Adriatic), especially in the areas featuring gravel or rubble bottoms. Morocco dentex ecologically prefers deep and highersalinity waters. This species is distributed in the southern and eastern Mediterranean (Maravelias et al. 2007) and the Atlantic (Bay of Biscay to Gulf of Guinea) (Froese and Pauly 2014). The major studies on the Morocco dentex in the Mediterranean have been carried on its western basin and concerned the age, growth, feeding, reproduction, and distribution (Nguyen and Wojciechowski 1972, Mennes 1985, Lamrini and Bouymajjane 2002,
Chemmam-Abdelkader et al. 2004, Maravelias et al. 2007). In the Aegean Sea (Saros Bay), a basin of the eastern-central Mediterranean, the sparids represent important components of the demersal fish stock and are generally caught by trawl, long line, and trammel nets. There is currently no information concerning the age, growth, and reproduction of this species or regarding the state of stocks in the Aegean Sea. Aspects concerning to the length-weight relation have been investigated, but these studies did not provide any population relations (Karakulak et al. 2006, Ceyhan et al. 2009).

As far as we know, this is the first report that provides a comprehensive picture of population parameters (length-weight relation, age, growth, reproduction, fecundity, first maturity length) of Dentex maroccanus, with the aim of generating sufficient information to improve future stock management and sustainable fishing.

\footnotetext{
${ }^{*}$ Correspondence: Mukadder ARSLAN MSc, Çanakkale Onsekiz Mart Üniversitesi, Deniz Bilimleri ve Teknolojisi Fakültesi, 17100, Çanakkale, Turkey, phone: +90 50521330 24, e-mail: (MA) mukadderarslan@gmail.com, (GG)guzingul@gmail.com, (AI) alismen@yahoo.com.

** İșmen A., Özekinci U., Özen Ö., Ayaz A., Altınağaç U., Yığın C., Ayyıldız H., Cengiz O., Arslan M., Ormancı H.B., Cakır F., Öz M.I. 2010. Saroz körfezi (Kuzey Ege Denizi) demersal balıklarının biyo-ekolojisi ve populasyon dinamiğinin belirlenmesi. [Determination of bioecology and population dynamics of demersal fish species in Saros Bay (North Aegean Sea).] TUBITAK Project Report 106Y035. [In Turkish.]
} 


\section{MATERIALS AND METHODS}

Samples of Dentex maroccanus were collected monthly between September 2006 and September 2008 at depths ranging from $20 \mathrm{~m}$ to $300 \mathrm{~m}$ in the Saros Bay, Aegean Sea, using a commercial bottom trawl net (Cengiz et al. 2014). The final data set comprised 184 hauls and a total of 507 specimens.

Total lengths (TL) of all fish were measured to the nearest $1 \mathrm{~cm}$ and nearest $1 \mathrm{~g}$ total weight $(W)$. Size of the otoliths were measured by stereomicroscope with a camera sensitive to $0.01 \mathrm{~mm}$. Gonad weight was determined to the nearest $0.01 \mathrm{~g}$, while sex and maturity stages were determined macroscopically. Stages of maturation were classified using the scale of Holden and Raitt (1974): immature (1), pre-mature (2), mature (3), spawning (4), and spent (5). Readings and interpretations of otoliths were based on the sagitta, which is the largest otolith (Beckman and Wilson 1995).

The length-weight relations were determined according to the allometric equation (Sparre and Venema 1989):

$$
W=a L^{b}
$$

where $W$ is the total body weight [g], L is the total length [cm], while $a$ is the intercept and $b$ is the slope of the regression.

The spawning season was determined by analyzing the temporal evolution in the relative frequency of maturity stages and gonadosomatic index (GSI ) (Anderson and Gutreuter 1983):

$$
\mathrm{GSI}=100 W_{\mathrm{G}} \cdot W_{E}^{-1}
$$

where $W_{\mathrm{G}}$ is the weight of the gonads and $W_{E}$ is the weight of eviscerated fish. Total fecundity was determined as the total number of oocytes in the ovaries (Valladolid and Przybylski 2008). Size at maturity was defined as the size at which $50 \%$ of individuals were mature. Specimens were grouped in $1-\mathrm{cm}$ size classes and the proportion of mature and immature individuals recorded (Fontana 1969, Cherif et al. 2007). The percentages of maturity by length class and sex were fitted to a logistic function using the Newton algorithm from Microsoft Excel ${ }^{\circledR}$ solver routine:

$$
F_{(L)}=\left(1+e^{-(\beta 0+\beta 1 L)}\right)^{-1}
$$

where $F_{(L)}$ is the proportion of mature fish at length $L, \beta_{0}$ is the intercept and $\beta_{1}$ is the regression coefficient (Piñeiro and Saínza 2003).

Sagittal otoliths from each fish were removed, cleaned, and stored in labelled Eppendorf tubes. Age was estimated by interpreting growth rings on 194 otoliths. All otoliths were immersed in glycerol in a Petri dish, then opaque and hyaline zones were counted by a stereozoom microscope illuminated from above with a magnification up to $10 \times$ using reflected light and a dark background. Age was determined by counting the annual ring marks on the surface of the otoliths. Growth parameters were estimated with the von Bertalanffy growth equation (Beverton and Holt 1957):

$$
L_{t}=L_{\infty}\left(1-e^{-k\left(t-t_{0}\right)}\right)
$$

where $L_{\infty}$ is the asymptotic length, $L_{t}$ is the length at age $t, K$ is the growth coefficient, and $t_{0}$ is the theoretical age when fish would have been at zero length. Growth parameters were estimated according to the nonlinear method using the FISAT (FAO-ICLARM Stock Assessment Tools) program package (Sparre and Venema 1989). The growth performance index (Pauly and Munro 1984) was estimated to compare growth rate by formula

$$
\varnothing^{\prime}=\log (k)+2 \times \log \left(L_{\infty}\right)
$$

A Kolmogorov-Smirnov two-sample test was used to determine if two datasets differed significantly and all statistical analyses were performed using SPSS 16.0.

\section{RESULTS}

A total of 507 Dentex maroccanus specimens were collected for this study, $185(82 \%)$ were females and 38 males (18\%) (Table 1). Approximately 30 specimens were caught each month. However, the minimum and maximum number of specimens was caught in July 2007 $(n=1)$ and October $2007(n=121)$, respectively. The sex of the remaining 280 fish could not be identified macroscopically due to their very thin and unclear gonads. Female-male ratio was $4.8: 1$. The majority of individual specimens were obtained from 50 to $100 \mathrm{~m}$ depth. A total of $52.37 \mathrm{~kg}$ specimens were collected and the mean CPUE was calculated at $0.5 \mathrm{~kg} \cdot \mathrm{h}^{-1}$ in Saros Bay.

Descriptive statistics for the length and weight measurements of Dentex maroccanus are presented in Table 1. The length and weight frequency distributions ranged from 8.9 to $25.2 \mathrm{~cm}$ in length and from 11.2 to $289.2 \mathrm{~g}$ in weight. The length frequency distribution in the $D$. maroccanus population showed that the most frequent size classes in females were 19-20 cm (about 35\%) whereas for males $21 \mathrm{~cm}$ was most frequent (about 27\%) (Fig. 1). Size frequency distribution between males and females was significantly different (Kolmogorov-Smirnov two sample test, $P<0.05$ ).

\begin{tabular}{|c|c|c|c|c|c|}
\hline \multirow{2}{*}{ Sex } & \multirow{2}{*}{$n$} & \multicolumn{2}{|c|}{ Total length } & \multicolumn{2}{|c|}{ Total weight } \\
\hline & & Mean \pm SE $[\mathrm{cm}]$ & Range $[\mathrm{cm}]$ & Mean \pm SE $[\mathrm{g}]$ & Range [g] \\
\hline Female & 185 & $18.4 \pm 0.17$ & $11.4-25.2$ & $96.7 \pm 2.58$ & $26.2-289.3$ \\
\hline Male & 38 & $19.7 \pm 0.42$ & $12.8-24.3$ & $120.0 \pm 7.71$ & $19.8-223.9$ \\
\hline Total & 507 & $17.7 \pm 0.13$ & $8.9-25.2$ & $89.7 \pm 1.77$ & $11.2-289.3$ \\
\hline
\end{tabular}

There were significant differences in length-weight relations between males and females $\left(\mathrm{df}=222, t_{s}=2.245\right.$,

Table 1

Descriptive statistics for length and weight of Dentex maroccanus from the Saros Bay

$n=$ number of specimens, $\mathrm{SE}=$ standard error. 


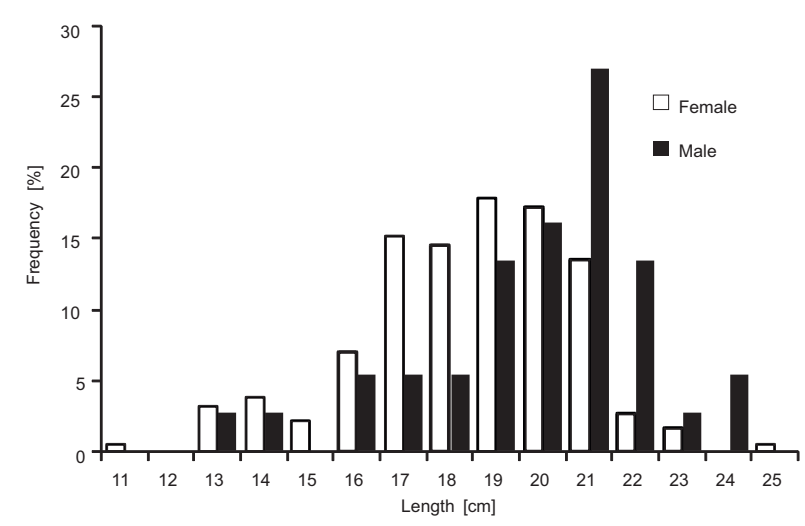

Fig. 1. Length frequency distribution by sex of Dentex maroccanus from the Saros Bay

$\left.t_{s}>t_{t}\right)$. Where $\mathrm{df}$ is degrees of freedom, $t_{s}$ is $t$ value of statistic and $t_{t}$ is value of $t$ table. Values for $b$ were 3.067 $\left(r^{2}=0.962\right)$ for females and $2.899\left(r^{2}=0.951\right)$ for males, which indicated negative growth for females and positive allometric growth for males $(t$-test, $P<0.05)$ (Table 2). The relation for combined sexes was $W=0.0144 \cdot L^{3.012}$ $\left(r^{2}=0.96\right)$

Age was determined by 124 specimens ranging between 1 to 3 years, whereas the estimated maximum age was 3 years. Age group $2(44 \%)$ was dominant followed by age group $3(30 \%)$ and age group $1(26 \%)$ (Table 3). The von Bertalanffy population growth parameters for D. maroccanus were estimated as $L_{\infty}=25.31 \mathrm{~cm}$, $K=0.49$ year $^{-1}$, and $t_{0}=-0.30$ year (Fig. 2).

An increase in GSI was observed for the Dentex maroccanus population from April-May to July (Fig. 3).
The percentage of each gonad development stage is illustrated in Fig. 4. Mature females of D. maroccanus were found mostly in the summer months (June-August). Conversely, immature and pre-mature individuals were most abundant in the winter months (December-May). Monthly variation of GSI and maturity stages showed that the spawning period occurs between June and September.

The fecundity of Dentex maroccanus increased with the growth of females. The relation between fecundity and length was described by the exponential equation

$$
F=0.981 \cdot L^{3.991}
$$

whereas ripe females in spawning condition were generally few in number (Fig. 5). Lengths of first maturity were 15.8 and $13 \mathrm{~cm}$ TL for males and females, respectively, and lengths at $100 \%$ maturity $\left(L_{100}\right)$ were $21 \mathrm{~cm}$ TL for females and $19 \mathrm{~cm}$ TL males, respectively (Fig. 6).

\section{DISCUSSION}

Dentex maroccanus is an economically important a species as the other Sparidae family members and Turkey's sea bream production is about 2700 tons in the fishery statistics (Anonymous 2013). Studies of the population dynamics required knowledge about the growth, reproduction, and age of the population. However, relatively little is known about $D$. maroccanus length-weight relation and growth parameters in Turkey. Reproduction period and first maturity length are important topics, but only few studies have been conducted on the reproduction of D. maroccanus (see Lamrini and Bouymajjane 2002).

In the Aegean Sea, the biology of this species is unknown and there is a gap in our knowledge on its growth and reproduction. This study therefore represents

Length-weight relation parameters for male and female Dentex maroccanus from the Saros Bay

\begin{tabular}{lccccc}
\hline Sex & $n$ & $a$ & $b$ & $r^{2}$ & $P$ \\
\hline Male & 38 & $0.020 \pm 0.101$ & $3.067 \pm 0.131$ & 0.962 & $<0.05$ \\
Female & 185 & $0.012 \pm 0.061$ & $2.899 \pm 0.048$ & 0.951 & $<0.05$ \\
Total & 507 & $0.014 \pm 0.032$ & $3.012 \pm 0.026$ & 0.960 & $<0.05$ \\
\hline
\end{tabular}

$n=$ number of specimens, $a=$ intercept,$b=$ slope of the regression, $r^{2}=$ coefficient of determination, $P=$ significance level.

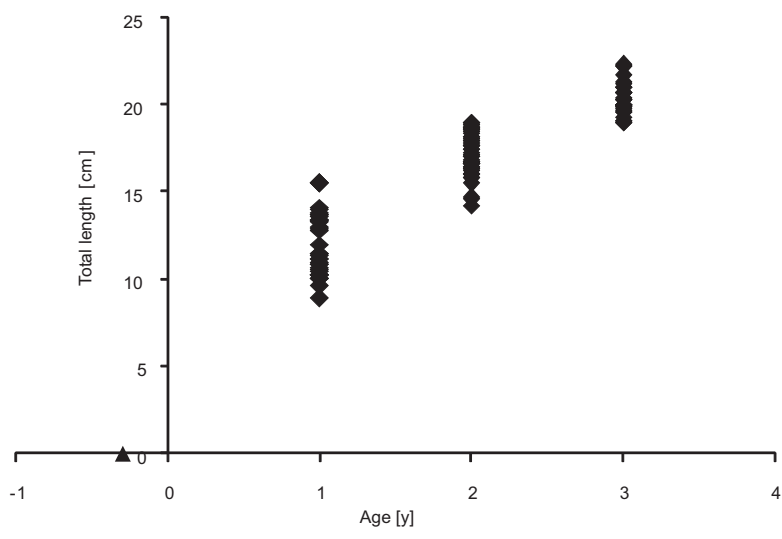

Fig. 2. Von Bertalanffy growth model for Dentex maroccanus by total length at age data in the Saros Bay

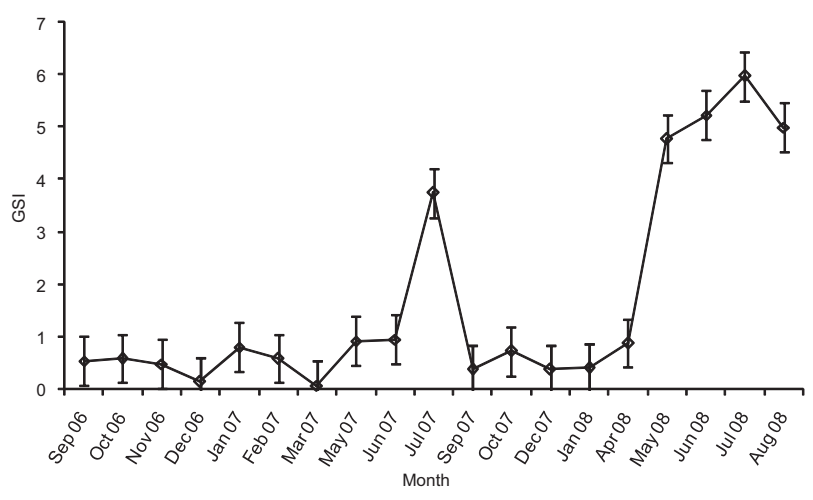

Fig. 3. Monthly variation of gonadosomatic index (GSI) values of female Dentex maroccanus from the Saros Bay 


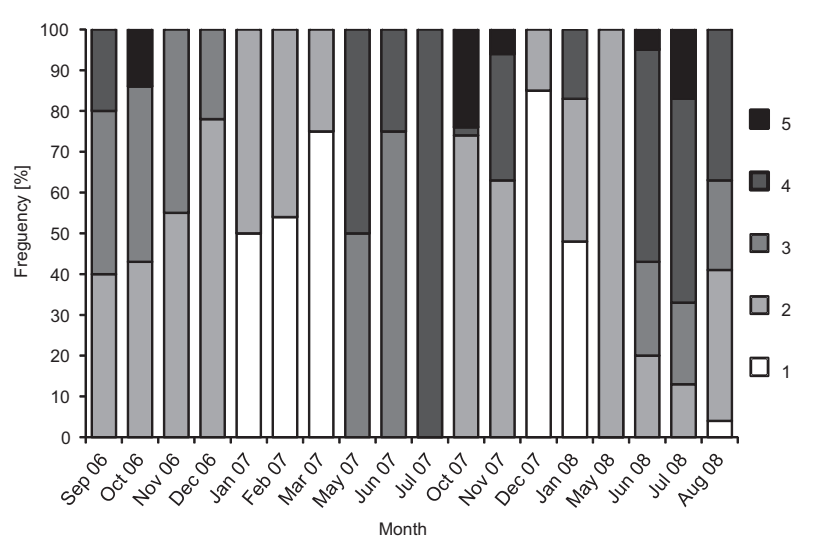

Fig. 4. Monthly variation of maturity stages for females of Dentex maroccanus from the Saros Bay $(1=$ immature, $2=$ maturing, $3=$ mature, $4=$ spawning, $5=$ spent)

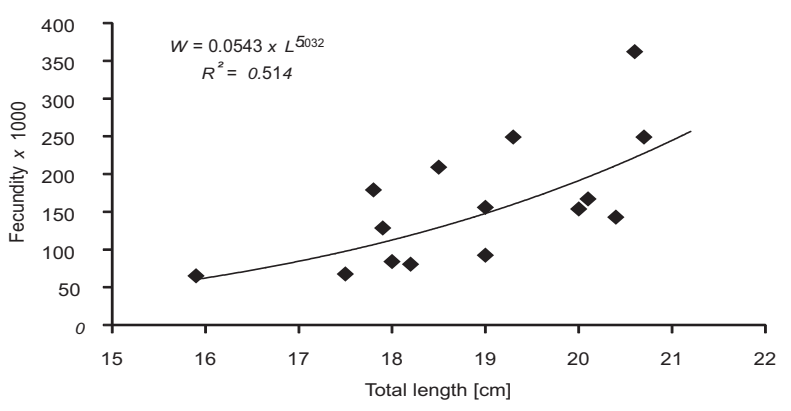

Fig. 5. Relation between fecundity and total length of Dentex maroccanus from the Saros Bay

Age-total length key for all individuals of Dentex maroccanus collected from the Saros Bay

\begin{tabular}{ccccc}
\hline \multirow{2}{*}{ TL $[\mathrm{cm}]$} & \multicolumn{3}{c}{ Age [years] } & $n$ \\
\cline { 2 - 4 } & 1 & 2 & 3 & \\
\hline 9 & 1 & & & 1 \\
10 & 8 & & & 8 \\
11 & 9 & & & 9 \\
12 & 3 & & & 3 \\
13 & 7 & & & 7 \\
14 & 6 & 1 & & 7 \\
15 & & 2 & & 2 \\
16 & 3 & 11 & & 14 \\
17 & & 16 & & 16 \\
18 & & 13 & & 13 \\
19 & & 11 & 5 & 16 \\
20 & & & 15 & 15 \\
21 & & & 9 & 9 \\
22 & & & 4 & 4 \\
\hline$n$ & 37 & 54 & 33 & 124 \\
$\%$ & 29.8 & 43.8 & 26.67 & 100 \\
MTL & 12.14 & 16.5 & 20.5 & \\
SE & 0.29 & 0.10 & 0.15 & \\
\hline
\end{tabular}

$\mathrm{TL}=$ total length, $n=$ number of specimens, MTL $=$ mean total length, $\mathrm{SE}=$ standard errorr. the first report on growth, reproduction, and length at first maturity of Dentex maroccanus in the Aegean Sea.

The results showed that the total length (TL) at which D. maroccanus first reached maturity was $15.8 \mathrm{~cm}$ for females and $13 \mathrm{~cm}$ for males. In this study, the reproduction period was defined based on the monthly changes in GSI. The GSI values started to increase after the winter months, and then decreased in summer (Fig. 4). This continued until the beginning of spawning. It decreased rapidly with the start of reproduction. Lamrini and Bouymajjane (2002) indicated that first sexual maturity occurred at $15.6 \mathrm{~cm}$ and this size corresponds to the age of 2 years and a reproduction period from March to September. Additionally, Bauchot and Hureau (1986) noted a spawning period in spring and maturity being reached at $10 \mathrm{~cm}$ in the Mediterranean.

Fecundity is used to understand the reproduction potential of the spawning stock. However, it must be noted that there has been no specific study on the fecundity of D. maroccanus. In the presently reported study the fecundity ranged from 65000 to 362000 eggs in Saros Bay. The environmental factors, such as temperature may affect fish behaviour and metabolism, and populations show differences in size at maturity and spawning time, (Murua et al. 2003), which may caused of variation among the GSI values of D. maroccanus in summer 2007 and summer 2008 .

Maximum age was determined for Dentex maroccanus to be 3 years, although other studies reported a maximum of 10 years (Nguyen and Wojciechowski 1972).

The reason for this difference might be that the size range of this study is lower than that of other studies. Parameters of the von Bertalanffy growth equation used by different authors are given in Table 4. $\Phi$-test indicated that there were no significant differences between von Bertalanffy growth parameters of other studies $\left(t_{s}<t_{t}\right)$.

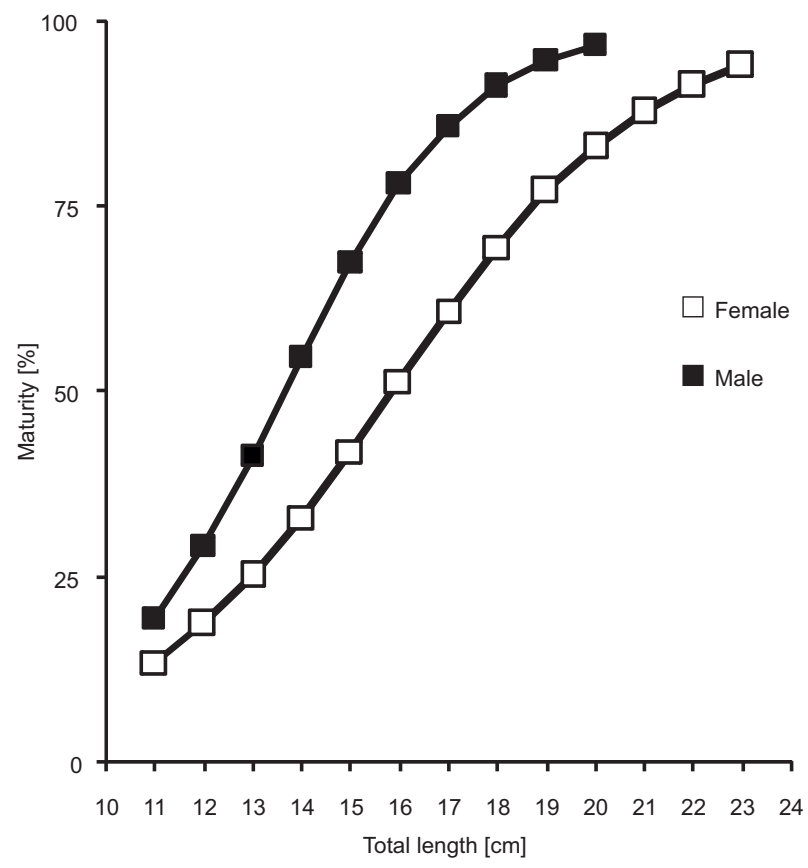

Fig. 6. Length at first maturity for females and males of Dentex maroccanus from the Saros Bay 
Table 4

Parameters of von Bertalanffy growth equation $\left(K, L_{\infty}, t_{0}\right)$ for Dentex maroccanus provided by different authors

\begin{tabular}{llcccccc}
\hline Author & Region & $\begin{array}{c}\text { Age } \\
\text { [year] }\end{array}$ & $\begin{array}{c}L_{\infty} \\
{[\mathrm{cm}]}\end{array}$ & $\begin{array}{c}K \\
{[\text { year] }}\end{array}$ & $\begin{array}{c}t_{0} \\
{\left[\text { year }^{-1}\right]}\end{array}$ & Sex & $\varnothing^{\prime}-$ \\
\hline Nguyen and Wojciechowski 1972 & Cape verde & $1-10$ & 32.5 & 0.18 & -0.62 & - & 2.28 \\
Nguyen and Wojciechowski 1972 & Cape Blanc & $1-10$ & 34.3 & 0.18 & -0.49 & - & 2.33 \\
Mennes 1985 & Morocco & - & 39.0 & 0.32 & - & - & 2.54 \\
Chemmam-Abdelkader et al. 2004 & Morocco & $1-7$ & 33.9 & 0.18 & -1.59 & $\mathrm{M}$ & 2.33 \\
Chemmam-Abdelkader et al. 2004 & Morocco & $1-7$ & 35.9 & 0.16 & -1.85 & $\mathrm{~F}$ & 2.3 \\
Lamrini and Bouymajjane 2002 & Morocco & $1-7$ & 30.2 & 0.16 & -1.97 & $\mathrm{M}$ & - \\
Lamrini and Bouymajjane 2002 & Morocco & $1-7$ & 31.5 & 0.18 & -1.63 & $\mathrm{~F}$ & - \\
This study & Saros Bay & $1-3$ & 25.3 & 0.49 & -0.30 & $\sum$ & 2.16 \\
\hline
\end{tabular}

$L_{\infty}=$ theoretical asymptotic length, $K=$ growth rate coefficient, $t_{0}=$ theoretical age when fish length is zero, $\varnothing^{\prime}=$ growth performance index.

Table 5

Estimates of total length - total weight relations for Dentex maroccanus provided by different authors

\begin{tabular}{llcccccc}
\hline Author & Region & Sex & $\begin{array}{c}\text { Length range } \\
\text { [cm] }\end{array}$ & $n$ & $a$ & $b$ & $r^{2}$ \\
\hline Nguyen and Wojciechowski 1972 & African coasts & F + M & - & - & 0.016 & 3.06 & - \\
Mennes 1985 & Morocco & F + M & - & - & 0.021 & 3 & - \\
Lamrini and Bouymajjane 2002 & Morocco & F & - & 134 & 0.012 & 3.15 & - \\
Lamrini and Bouymajjane 2002 & Morocco & F + M & - & 297 & 0.084 & 3.3 & - \\
Chemmam-Abdelkader et al. 2004 & Morocco & F + M & $12.2-27.1$ & 349 & 0.14 & 3.02 & 0.991 \\
Karakulak et al. 2006 & N Aegean Sea & F + M & $18.9-34.0$ & 9 & 0.008 & 3.18 & 0.996 \\
Ismen et al. 2007 & Saros Bay & F + M & $14.2-26.5$ & 146 & 0.028 & 2.724 & 0.925 \\
Ceyhan et al. 2009 & Gökova Bay & F + M & $14.8-21.8$ & 8 & 0.119 & 2.29 & 0.904 \\
Presently reported study & Saros Bay & F & $11.4-25.2$ & 185 & 0.02 & 2.899 & 0.84 \\
Presently reported study & Saros Bay & M & $12.8-24.3$ & 38 & 0.01 & 3.067 & 0.98 \\
Presently reported study & Saros Bay & F + M & $8.9-25.2$ & 507 & 0.144 & 3.012 & 0.96 \\
\hline
\end{tabular}

$n=$ number of specimens, $a=$ intercept, $b=$ slope of the regression, $r^{2}=$ coefficient of determination, $\mathrm{F}=$ female, $\mathrm{M}=$ male.

Previous studies providing length-weight relations for Dentex maroccanus are given in Table 5 for comparative purposes. There were some studies about length-weight relation of $D$. maroccanus but only two such studies were conducted in the Aegean Sea. Differences in the number of individual specimens may also affect the relations. However, the differences between $b$ values are due to one or more factors: the season and effects of origin, sex, and food availability (Pauly and Munro 1984, Cherif et al. 2007).

The results of the presently reported study will contribute to knowledge concerning age composition, growth and reproduction of Dentex maroccanus in the Saros Bay and also to a better understanding of its role in the marine ecosystem. This information will help fisheries scientists in future studies of D. maroccanus populations, as well as providing some basic fundamental knowledge about the species and helping to enforce regulations on commercial fisheries with regard to minimum landing size restrictions.

\section{ACKNOWLEDGEMENTS}

The presently reported study was carried out with financial support of TUBITAK 106Y035. The authors would like to thank all the staff who helped in the field work and in the laboratory.

\section{REFERENCES}

Anderson R.O., Gutreuter S.J. 1983. Length, weight, and associated structural indices. Pp. 284-300. In: Nielsen L., Johnson D. (eds.) Fisheries techniques. American Fisheries Society, Bethesda, MD, USA.

Anonymous 2013. Su Ürünleri İstatistikleri Fishery Statistics 2013. Yayın No Publication Number 4349. Türkiye İstatistik Kurumu Turkish Statistical Institute, Ankara, Turkey. [In Turkish and in English.]

Arculeo M., Lo Brutto S., Sirna-Terranova M., Maggio T., Cannizzaro L., Parrinello N. 2003. The stock genetic structure of two Sparidae species, Diplodus vulgaris and Lithognathus mormyrus, in the Mediterranean Sea. Fisheries Research 63 (3): 339-347. DOI: 10.1016/S0165-7836(03)00102-4

Bauchot M.L., Hureau J.C. 1986. Sparidae. Pp. 883-907. In: Whitehead P.J.P., Bauchot M.L., Hureau J.C., Nielsen J., Tortonese E. (eds.) Fishes of the North-Eastern Atlantic and the Mediterranean. Vol. 2. UNESCO, Paris. 
Beckman D.W., Wilson C.A. 1995. Seasonal timing of opaque zone formation in fish otoliths. Pp. 27-44. In: Secor D.H., Dean J.M., Campana S.E. (eds.) Recent developments in fish otolith research. University of South Carolina Press, Columbia, SC, USA.

Beverton R.J.H., Holt S.J. 1957. On the dynamics of exploited fish populations. Book series: Great Britain Fishery Investigations, Series 2, Vol. 19.

Cengiz Ö., Ismen A., Ozekinci U. 2014. Reproductive biology of the spotted flounder, Citharus linguatula (Actinopterygii: Pleuronectiformes: Citharidae), from Saros Bay (northern Aegean Sea, Turkey). Acta Ichthyologica et Piscatoria 44 (2): 123-129. DOI: 10.3750/AIP2014.44.2.06

Ceyhan T., Akyol O., Erdem M. 2009. Length-weight relationships of fishes from Gökova Bay, Turkey (Aegean Sea). Turkish Journal of Zoology 33 (1): 69-72. DOI: 10.3906/zoo-0802-9

Chemmam-Abdelkader B., Kraïem M.M., El Abed A. 2004. Etude de l'age et de la croissance de deux especes de Dentes (Dentex dentex et de Dentex maroccanus) des cotes tunisiennes. Bulletin de I'Institut National des sciences et technologies de la Mer de Salammbô 31: 43-51.

Cherif M., Zarrad R., Gharbi H., Missaoui H., Jarboui O. 2007. Some biological parameters of the red mullet, Mullus barbatus L., 1758, from the Gulf of Tunis. Acta Adriatica 48 (2): 131-144.

Fontana A. 1969. Étude de la maturité sexuelle des sardinelles Sardinella eba (Val) et Sardinella aurita C. et V. de la région de Pointe-Noire. Cahiers ORSTOM, série océanographie 7 (2): 101-114.

Froese R., Pauly D. (eds.) 2014. FishBase. [version 08/2014] http://www.fishbase.org.

Holden M.J., Raitt D.F.S. 1974. Manual of fisheries science. Part 2. Methods of resource investigation and their application. FAO Fisheries Technical Paper No. 155 (Rev. 1).

Ismen A., Ozen O., Altinagac U., Ozekinci U., Ayaz A. 2007. Weight-length relationships of 63 fish species in Saros Bay, Turkey. Journal of Applied Ichthyology 23 (6): 707-708. DOI: 10.1111/j.1439-0426.2007.00872.x

Karakulak F.S., Erk H., Bilgin B. 2006. Length-weight relationships for 47 coastal fish species from the northern
Aegean Sea, Turkey. Journal of Applied Ichthyology 22 (4): 274-278. DOI: 10.1111/j.1439-0426.2006.00736.x

Lamrini A., Bouymajjane A. 2002. Biologie de Dentex maroccanus (Valenciennes, 1830) dans la région de Safi. Actes Institute Agronomique et Veterinaire (Maroc) 22 (1): 11-18.

Maravelias C.D., Tsitsika E.V., Papaconstantinou C. 2007. Evidence of Morocco dentex (Dentex maroccanus) distribution in the NE Mediterranean and relationships with environmental factors determined by Generalized Additive Modelling. Fisheries Oceanography 16 (3): 294-302. DOI: 10.1111/j.1365-2419.2007.00421.x

Mennes F. 1985. Multispecies assessment of fish stocks off the Western Sahara region with emphasis on the family Sparidae. Fishbyte 3 (3): 5-10.

Murua H., Kraus G., Saborido R.F., Witthames P.R., Thorsen A., Junquera S. 2003. Procedures to estimate fecundity of marine fish species in relation to their reproductive strategy. Journal of Northwest Atlantic Fishery Science 33: $33-54$.

Nguyen X.L., Wojciechowski J. 1972. Comparative biology of fish from genus Dentex (Sparidae) of north-west African coast. Acta Ichthyologica et Piscatoria 2 (2): 77-79.

Pauly D., Munro J.L. 1984. Once more on the comparison of growth in fish and invertebrates. Fishbyte 2 (1): 21.

Piñeiro C., Saínza M. 2003. Age estimation, growth and maturity of the European hake (Merluccius merluccius (Linnaeus, 1758)) from Iberian Atlantic waters. ICES Journal of Marine Science 60 (5): 1086-1102. DOI: $10.1016 / \mathrm{S} 1054-3139(03) 00086-9$

Sparre P., Venema S.C. 1998. Introduction to tropical fish stock assessment. Part 1: Manual. FAO Fisheries Technical Paper No. 306/1, Rev. 2. FAO, Rome.

Valladolid M., Przybylski M. 2008. Life history traits of the endangered Iberian loach Cobitis calderoni in the River Lozoya, central Spain. Folia Zoologica 57 (1-2): 147-154.

Received: 29 April 2014

Accepted: 16 September 2014 Published electronically: 31 December 2014 